\title{
PI3KIAKT is involved in mediating survival signals that rescue Ewing tumour cells from fibroblast growth factor 2-induced cell death
}

\author{
M Hotfilder ${ }^{1,3}$, P Sondermann ${ }^{1,3}$, A Sen $\beta^{\prime}$, F van Valen², H Jürgens' and J Vormoor,, \\ 'Department of Pediatric Hematology/Oncology, University Children's Hospital, Münster, Germany; ${ }^{2}$ Department of Orthopedics, 48 I 29 Münster, \\ Germany
}

\begin{abstract}
While in vitro studies had shown that fibroblast growth factor 2 (FGF2) can induce cell death in Ewing tumours, it remained unclear how Ewing tumour cells survive in vivo within a FGF2-rich microenvironment. Serum- and integrin-mediated survival signals were, therefore, studied in adherent monolayer and anchorage-independent colony cell cultures. In a panel of Ewing tumour cell lines, either adhesion to collagen or exposure to serum alone only had a minor protective effect against FGF2. However, both combined led to complete resistance to $5 \mathrm{ng} \mathrm{ml}^{-1}$ FGF2 in three of four FGF2-sensitive cell lines (RD-ES, RM-82 and WE-68), and to an increased survival as compared to other culture conditions in TC-7I cells. Inhibition studies with LY294002 demonstrated that the serum signal is mediated via the phosphoinositide 3-OH kinase/AKT pathway. Thus, Ewing tumour cells escape FGF2-induced cell death by modulating FGF2 signalling. The tumour microenvironment provides the necessary survival signals by integrin-mediated adhesion and soluble serum factor(s). These survival signals warrant further investigation as a potential resistance mechanism to other apoptosis-inducing agents in vivo.

British Journal of Cancer (2005) 92, 705-7I0. doi: 10.1038/sj.bjc.6602384 www.bjcancer.com

Published online I February 2005

(c) 2005 Cancer Research UK
\end{abstract}

Keywords: fibroblast growth factor 2; basic fibroblast growth factor; Ewing tumours; apoptosis; survival signals

The molecular hallmark of the diverse group of Ewing tumours are chromosomal translocations leading to the fusion of the EWS gene on chromosome 22 with different members of the ETS family of transcription factors (de Alava and Gerald, 2000). The EWS/ETS fusion proteins appear (i) to act as abnormal transcription factors regulating a network of target genes (e.g., manic fringe, PDGF-C, TGF $\beta$ II receptor) (Arvand and Denny, 2001) and (ii) to influence post-transcriptional gene processing by interacting with components of the cellular splicing machinery (e.g., TASR, SF1 and U1C) (Knoop and Baker, 2001). Both effects are thought to be important for the formation of the malignant phenotype. Despite the progress in unravelling the molecular biology of this tumour entity, the exact mechanisms that govern growth and survival of Ewing tumours in vivo are still poorly understood.

Fibroblast growth factor (FGF2) (formerly: basic fibroblast growth factor (bFGF)) is a classical growth and differentiation factor that is ubiquitously expressed and belongs to a family of heparin-binding, single-chain polypeptides. It is present in the extracellular matrix where it is bound to heparan sulphate proteoglycan. It influences a variety of biological processes including cell growth and differentiation and angiogenesis. High levels of FGF2 activity in tumour cells suggested a role in cell proliferation and

\footnotetext{
* Correspondence: Priv-Doz Dr med J Vormoor, Universitätsklinikum Münster, Klinik und Poliklinik für Kinderheilkunde - Pädiatrische Hämatologie/Onkologie, Albert-Schweitzer-Str. 33, 48/49 Münster, Germany; E-mail: vormoor@uni-muenster.de

${ }^{3}$ These authors contributed equally to this work

Revised 4 October 2004; accepted I 5 December 2004; published online I February 2005
}

tumour angiogenesis (Ornitz and Itoh, 2001). Introduction of an FGF2 cDNA expression vector in hamster kidney fibroblasts induced serum- and anchorage-independent growth (Neufeld et al, 1988), demonstrating the oncogenic potential of FGF2.

Nearly 15 years ago, Schweigerer and co-workers isolated FGF2 from Ewing tumour cells. Unexpectedly, they demonstrated that this classical growth and differentiation factor induced growth arrest rather than proliferation in Ewing tumour cells in vitro (Schweigerer et al, 1987). Recent investigations showed that this growth arrest is accompanied by features characteristic of apoptotic cell death (Sturla et al, 2000; Westwood et al, 2002).

These results led to the question how Ewing tumour cells survive in an FGF2-containing environment in vivo? Modulation of FGF2induced apoptosis by potential survival signals was the primary focus of this study. It has recently been pointed out that standard monolayer cultures may only poorly reflect the in vivo environment of Ewing tumour cells (Lawlor et al, 2002). Only a limited number of signalling cascades, required for tumour cell growth and survival in vivo, are triggered. Therefore, in this study potential survival signals, for example, integrin-mediated adhesion or soluble growth factors, that may counteract FGF2-induced cell death were studied under different in vitro conditions including anchorage-independent colony and adherent monolayer cultures.

\section{MATERIALS AND METHODS}

\section{Cell culture and chemicals}

The Ewing tumour cell lines CADO-ES1 and RD-ES were purchased from the DSMZ, Braunschweig, Germany. The TC-71 
cell line was provided by Professor TJ Triche (Whang-Peng et al, 1984). RM-82, VH-64, and WE-68 were established by one of the authors (van Valen, 1999). All cell lines were maintained in RPMI 1640 medium (Biochrom, Berlin, Germany) containing 10\% FCS, $2 \mathrm{mM}$ L-glutamine, $100 \mathrm{U} \mathrm{ml}^{-1}$ penicillin and $100 \mu \mathrm{g} \mathrm{ml}^{-1}$ streptomycin (all Lifetechnologies, Karlsruhe, Germany) at $37^{\circ} \mathrm{C}$ in a humidified $5 \% \mathrm{CO}_{2}$ atmosphere. Cells were cultured in collagencoated $25 \mathrm{~cm}^{2}$ tissue culture flasks (Greiner Labortechnik, Solingen, Germany). All cell lines were regularly tested for mycoplasma contamination. Lyophilised FGF2 (Sigma, Deisenhofen, Germany) was dissolved in IMDM (Lifetechnologies) at $5 \mu \mathrm{g} \mathrm{ml}^{-1}$ (aliquoted and stored at $-20^{\circ} \mathrm{C}$ until required). TNF-related apoptosisinducing factor (TRAIL, PeproTech Inc., Rocky Hill, NJ, USA) was dissolved in PBS at $50 \mu \mathrm{g} \mathrm{ml}^{-1}$. The phosphoinositide 3-OH kinase (PI3K) inhibitor LY294002 and the caspase inhibitors Ac-DEVDCHO, z-IETD-FMK and z-VAD-FMK (all from Calbiochem, Bad Soden, Germany) were dissolved in DMSO at 50, 20, 10 and $20 \mathrm{mM}$, respectively.

\section{In vitro growth assays}

Anchorage-independent growth was analysed by plating Ewing tumour cells as a single-cell suspension in semisolid medium containing $0.9 \%\left(\mathrm{w} \mathrm{v}^{-1}\right)$ methylcellulose in IMDM, 15\% FCS $\left(\mathrm{vv}^{-1}\right)$ and $0.5 \%\left(\mathrm{wv}^{-1}\right)$ BSA. For serum-free assays, cells were plated in semisolid medium containing $0.9 \%$ methylcellulose in IMDM, 2.5\% $\left(\mathrm{w} \mathrm{v}^{-1}\right)$ BSA and a supplement including $25 \mu \mathrm{g} \mathrm{ml}^{-1}$ insulin, $50 \mu \mathrm{g} \mathrm{ml}^{-1}$ transferrin, $6 \mu \mathrm{g} \mathrm{ml}^{-1}$ cholesterol and $14 \mu \mathrm{g} \mathrm{ml}^{-1}$ linoleic acid (all purchased from Sigma). For each assay, $1 \mathrm{ml}$ of the cell suspension was plated in duplicate, triplicate or quadruplicate into sterile $35 \mathrm{~mm}$ Petri dishes (Nunc, Karlsruhe, Germany) that were incubated at $37^{\circ} \mathrm{C}$. Colonies were counted after 11-14 days and each experiment was repeated at least two times.

Growth characteristics of adherent cells were investigated by utilising the assay described by Hansen et al (1989). $2 \times 10^{4}$ cells were plated in quadruplicate in $100 \mu \mathrm{l}$ of RPMI $1640,10 \%$ FCS, Lglutamin, penicillin and streptomycin or, for serum-free conditions, in $100 \mu \mathrm{l}$ IMDM containing $2 \%$ BSA $\left(\mathrm{wv}^{-1}\right)$ and supplemental factors (as described above) in collagen-coated 96-well plates (Becton Dickinson, Heidelberg, Germany). Cells were allowed to attach for $3 \mathrm{~h}$ at $37^{\circ} \mathrm{C}$ with $5 \% \mathrm{CO}_{2}$. Afterwards FGF2 was added. In experiments using caspase or PI3K inhibitors, these were added $1 \mathrm{~h}$ prior to FGF2 treatment. After different time intervals $(24-72 \mathrm{~h}), 20 \mu \mathrm{l}$ of a $5 \mathrm{mg} \mathrm{ml}^{-1}$ MTT solution (3-(4,5dimethylthiazol-2-yl)-2,5-diphenyltetrazolium bromide; Sigma) was added for $4 \mathrm{~h}$ at $37^{\circ} \mathrm{C}$ to each well. The media were replaced by $100 \mu \mathrm{l}$ of lysis solution $\left(50 \%\left(\mathrm{v} \mathrm{v}^{-1}\right) \mathrm{N}, N\right.$-dimethylformamide, $20 \%\left(\mathrm{w} \mathrm{v}^{-1}\right)$ SDS) (to dissolve the formazan crystals) and plates were read at $550 \mathrm{~nm}$ (test wavelength) and $630 \mathrm{~nm}$ (reference wavelength) in a Dynatech MR 7000 microplate reader (Denkendorf, Germany). Each experiment was repeated at least two times. Results are expressed as percentage of controls. The paired $t$-test was performed for statistical analysis.

\section{Detection of FGF2 protein}

Crude cell lysates were obtained by resuspending $4 \times 10^{6}$ cells in $1 \mathrm{ml}$ extraction buffer $(100 \mathrm{~mm}$ Tris $-\mathrm{HCl}, \mathrm{pH} 8.0,0.5 \%$ Triton X$100,10 \mathrm{~mm}$ EDTA). Samples were subjected to three rounds of $5 \mathrm{~min}$ in liquid nitrogen, $5 \mathrm{~min}$ at $37^{\circ} \mathrm{C}$ and $5 \mathrm{~min}$ on ice. Samples were centrifuged, aliquoted and stored at $-20^{\circ} \mathrm{C}$. For analysis of FGF2 protein in crude cell lysates and supernatant, a FGF2-ELISA (R\&D, Wiesbaden-Nordenstadt, Germany) was applied.

\section{Characterisation of cell death}

Cells were grown in collagen-coated $25 \mathrm{~cm}^{2}$ tissue culture flasks containing media and $5 \mathrm{ng} \mathrm{m}^{-1}$ FGF2 for up to $48 \mathrm{~h}$. Cells were harvested and labelled using an annexin V-FITC apoptosis detection kit (Pharmingen, Heidelberg, Germany). Annexin Vpositive cells were quantified by flow cytometry on a FACScan (Becton Dickinson) using CellQuest software (Becton Dickinson).

\section{RESULTS}

\section{Fibroblast growth factor inhibits proliferation of clonogenic Ewing tumour cells}

It has been well established that FGF2 inhibits proliferation of Ewing tumour cell lines in vitro (Schweigerer et al, 1987; Sturla et al, 2000; Westwood et al, 2002) though conflicting results have recently been reported under serum-free culture conditions (Girnita et al, 2000). To quantify this inhibitory effect of FGF2 on clonogenic tumour cells, the cell line TC-71 was plated in methylcellulose at different concentrations of FGF2.

Under serum-free conditions, FGF2 at concentrations ranging from 50 down to $0.5 \mathrm{ng} \mathrm{ml}^{-1}$ (Figure 1) completely abrogated the colony-forming ability of TC-71 cells. However, in the presence of $15 \%$ FCS, TC-71 cells were less sensitive to $0.5 \mathrm{ng} \mathrm{ml}^{-1}$ FGF2. This protective effect of serum could be overcome by higher concentrations of FGF2. No stimulatory response to FGF2 at concentrations as high as $50 \mathrm{ng} \mathrm{m}^{-1}$ was observed under any conditions.

\section{Ewing tumour cells express FGF2 as well as its receptors}

Expression of FGF2 was assessed in a panel of Ewing tumour cell lines. Fibroblast growth factor protein could be detected in crude cell lysates from all the six cell lines, while no FGF2 protein could be detected in the supernatant of these cells (Table 1).

In order to identify the receptor(s) that transduces the inhibitory FGF2 signal in Ewing tumour cells, Western blot analyses identified FGFR1, -2 protein in all cell lines, whereas FGFR-3 protein was only detected in TC-71, VH-64 and WE-68. No FGFR-4 protein was found despite the presence of FGFR4-mRNA (data not shown). The Western blot results, therefore, confirm and extend previous studies (Sturla et al, 2000) by detection of FGFR1, -2 and -3 on the protein level in a high percentage of Ewing tumour cell lines.

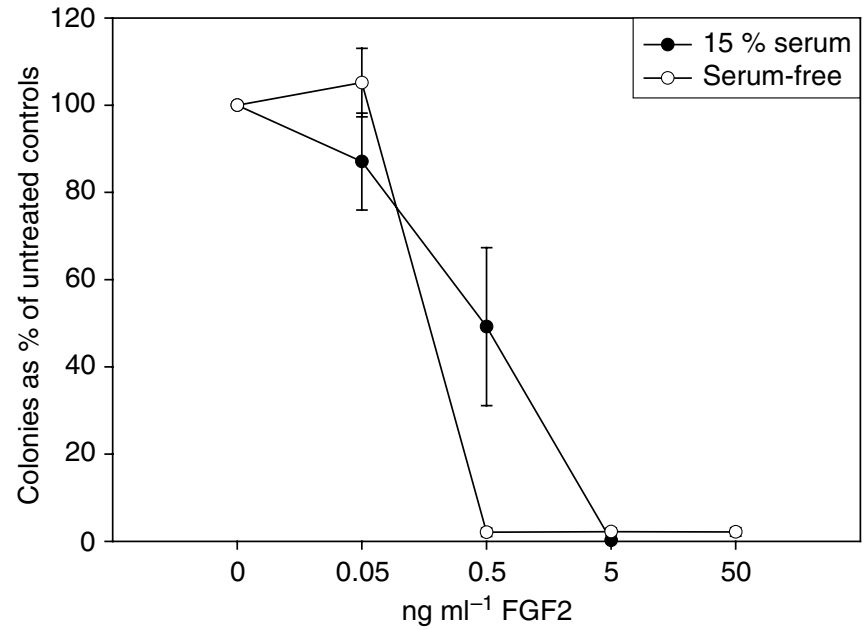

Figure I Increasing concentrations of FGF2 decreased the colonyforming potential of TC-7I cells in serum-containing (black dots) and serum-free (white dots) colony assays. This inhibitory effect was significant $(P<0.05)$ for concentrations $>0.5 \mathrm{ng} \mathrm{ml}^{-1}$. Notably, 15\% FCS protected approx. $55 \%$ of the colony-forming ability of TC-7I at low concentrations of FGF2 $\left(0.5 \mathrm{ng} \mathrm{ml}^{-1}\right)$. 
Table I Detection of FGF2 in cell lysates and supernatants in a panel of Ewing tumour cell lines

\begin{tabular}{|c|c|c|}
\hline \multirow[b]{2}{*}{ Cell line } & \multicolumn{2}{|c|}{ Protein in } \\
\hline & Supernatant $\mathrm{pg} / 10^{6}$ cells & Cell lysate $\mathrm{pg} / 10^{6}$ cell \\
\hline CADO-ESI & $\ldots^{a}$ & $47.3+6.9$ \\
\hline RD-ES & - & $0.75 \pm 0.009$ \\
\hline RM-82 & - & $20.7 \pm 1.1$ \\
\hline TC-7| & - & $35.5 \pm 4.1$ \\
\hline $\mathrm{VH}-64$ & - & $9.2 \pm 0.4$ \\
\hline WE-68 & - & $78.9 \pm 0.6$ \\
\hline L87/4 (BM stroma) & $278.3 \pm 21.7$ & $3422 \pm 110$ \\
\hline Medium (I0\% FCS) & - & \\
\hline Medium (0\% FCS) & - & \\
\hline
\end{tabular}

${ }^{a}-$ : values obtained were below the detection limit of $10 \mathrm{n} \mathrm{ml}^{-1}$

\section{Fibroblast growth factor-induced growth arrest is accompanied by caspase-dependent apoptosis}

In order to analyse the events accompanied by FGF2-induced growth inhibition, FGF2-treated cells were studied for markers of apoptosis. An early feature of apoptotic cells is exposure of phosphatidyl serines on the cell surface, which are recognised by the annexin $\mathrm{V}$ antibody. Consistent with published reports (Westwood et al, 2002), an annexin V single-positive population could be detected after $24 \mathrm{~h}$ treatment with FGF2 (data not shown).

Caspases are essential proteases during apoptotic cell death. In order to define whether caspases are involved in FGF2-induced apoptosis, a panel of caspase inhibitors were applied: z-VAD-FMK - a pan-caspase inhibitor; Ac-DEVD-CHO - primarily an inhibitor of the effector caspase 3 and, to a lesser extent, caspase 7 and 8; zIETD-FMK - an inhibitor of the initiator caspase 8. As shown in Figure 2, pre-incubation of TC-71 cells with these inhibitors did not completely protect TC-71 cells from FGF2-induced cell death: $\mathrm{z}$-VAD rescues approx. $67 \%(67.1+15.1 \%)$ of the cells, the caspase 3 inhibitor Ac-DEVD-CHO protects only $35 \%(34.8 \pm 12.5 \%$, data not shown) of the cells from apoptosis. In contrast, the caspase 8 inhibitor as well as the pan-caspase inhibitor were able to completely protect TC-71 cells from TRAIL-induced apotosis (Figure 2), indicating the effectiveness of the used inhibitors. These results confirm that FGF2-induced cell death is in part mediated via caspase activation. Interestingly and in contrast to TRAILinduced apoptosis, the caspase 8 inhibitor z-IETD-FMK has no protective effect against FGF2-induced apoptosis (Figure 2).

\section{Adequate survival signals rescue Ewing tumour cells from FGF2-induced apoptosis}

The obtained data confirm and extend recent findings showing that Ewing tumour cells express FGF2 and its receptors and that extracellularly supplied FGF2 induces apoptosis (Schweigerer et al, 1987; Sturla et al, 2000; Westwood et al, 2002). This leads to the central question how Ewing tumour cells survive and proliferate in an FGF2-containing environment in vivo.

To address this question, Ewing tumour cell survival in the presence of FGF2 was studied under different culture conditions. Monolayer cultures on collagen-coated culture flasks under defined serum-free conditions were used as a model for integrinmediated survival signals. Spheroid cell cultures are regarded as suitable models for three-dimensional growth and cell-cell interactions of in vivo tumours (Santini and Rainaldi, 1999). Unlike the spheroid liquid-overlay cultures that allow aggregation of tumour cells (Santini and Rainaldi, 1999; Lawlor et al, 2002), the methylcellulose assay reads out single cells with the ability of clonal expansion, an important feature of metastatic cells.

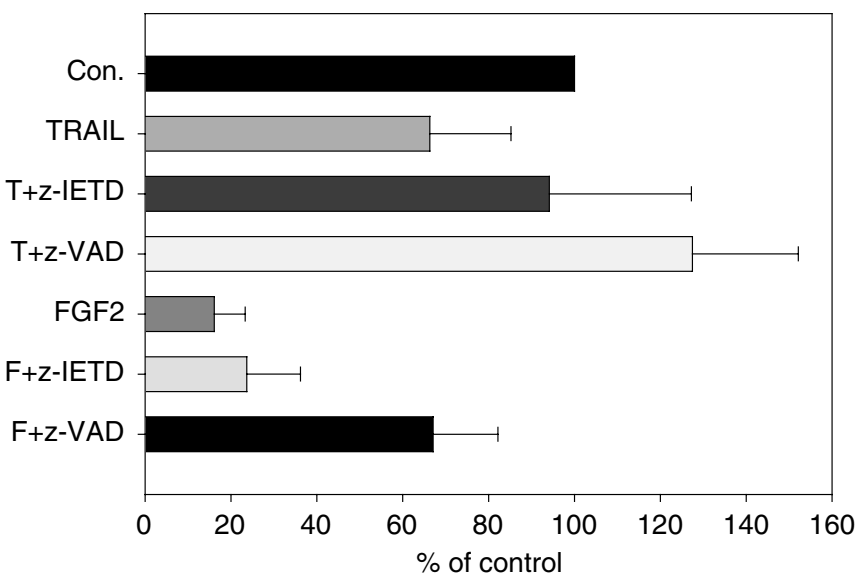

Figure 2 Both FGF2 and TRAIL inhibited proliferation of TC-7I Ewing tumour cells in serum-free monolayer cultures by induction of apoptosis. While TRAIL-induced apoptosis could be blocked both by the caspase 8 inhibitor z-IETD-FMK and pan-caspase inhibitor z-VAD-FMK, FGF2-induced apoptosis was only significantly inhibited by z-VAD-FMK $(P<0.005)$. This indicates that the FGF2-induced death signal is not mediated via caspase 8. Con.: untreated control; TRAIL: $50 \mathrm{ng} \mathrm{ml}^{-1}$ TRAIL; T+z-IETD: $25 \mu \mathrm{M} \mathrm{z}$ IETD-FMK I h before TRAIL; T + z-VAD: $50 \mu \mathrm{M}$ of z-VAD-FMK I h before TRAIL; FGF2: $5 \mathrm{ng} \mathrm{ml}^{-1}$ FGF2; F + z-IETD: $25 \mu \mathrm{M}$ z-IETD-FMK I h before FGF2; F + z-VAD: $50 \mu \mathrm{M}$ of $z-V A D-F M K ~ I ~ h$ before FGF2.

Two cell lines (CADO-ES1 and VH-64) were resistant to FGF2 under all culture conditions (data not shown). Four cell lines (RDES, RM-82, TC-71 and WE-68) were FGF2-sensitive, but distinct culture conditions were able to rescue these cell lines from FGF-2induced apoptosis. Exposure to serum alone (in the presence of $15 \%$ foetal calf serum) or integrin-mediated adhesion (serum-free monolayer cultures on a collagen matrix), both rendered one of the four Ewing tumour cell lines at least partially resistant to $5 \mathrm{ng} \mathrm{ml}^{-1}$ FGF-2 (serum in RD-ES and adhesion in RM-82; Figure 3A and B). However, integrin-mediated adhesion combined with serum (monolayer cultures on a collagen matrix with $15 \%$ FCS) provides a strong synergistic survival signal: under these conditions, three out of the four cell lines are completely resistant to $5 \mathrm{ng} \mathrm{ml}^{-1}$ FGF2 and $37.2 \pm 10.3 \%$ of TC-71 cells are protected from FGF2-induced apoptosis (Figure 3C).

Previous studies suggested insulin-like growth factor 1 (IGF1) as one of the key growth factors of Ewing tumours (van Valen et al, 1992; Scotlandi et al, 1996, 2002). It was, therefore, investigated whether serum-derived IGF1 may be the/one of the protective factor/s antagonising FGF2. However, IGF1 at $0.2-20 \mathrm{ng} \mathrm{ml}^{-1}$ neither increased the colony-forming ability and proliferative activity of Ewing tumour cells under serum-free conditions, nor was IGF1 sufficient to protect TC-71 cells from FGF2-induced apoptosis (data not shown).

\section{Phosphoinositide 3-OH kinase is involved in integrin- and serum-mediated survival signals}

The PI3K/AKT pathway is considered to be an important signalling pathway mediating survival signals in Ewing tumour cells. Activation of AKT leads to phosphorylation and inactivation of proapoptotic molecules such as bad, forkhead and caspase 9, and activation of molecules regulating cell growth and expression of genes responsible for survival (Datta et al, 1999). Inhibition of this signalling pathway in Ewing tumour cells with the PI3K specific inhibitor LY294002 has been reported to enhance apoptosis (Toretsky et al, 1999). In addition, it has been shown that integrin signalling renders tumour cells insensitive to apoptosis-inducing drugs (Aoudjit and Vuori, 2001) and this resistance is also mediated by the PI3K/AKT pathway. 
A Colony assay (15\% FCS) + FGF2
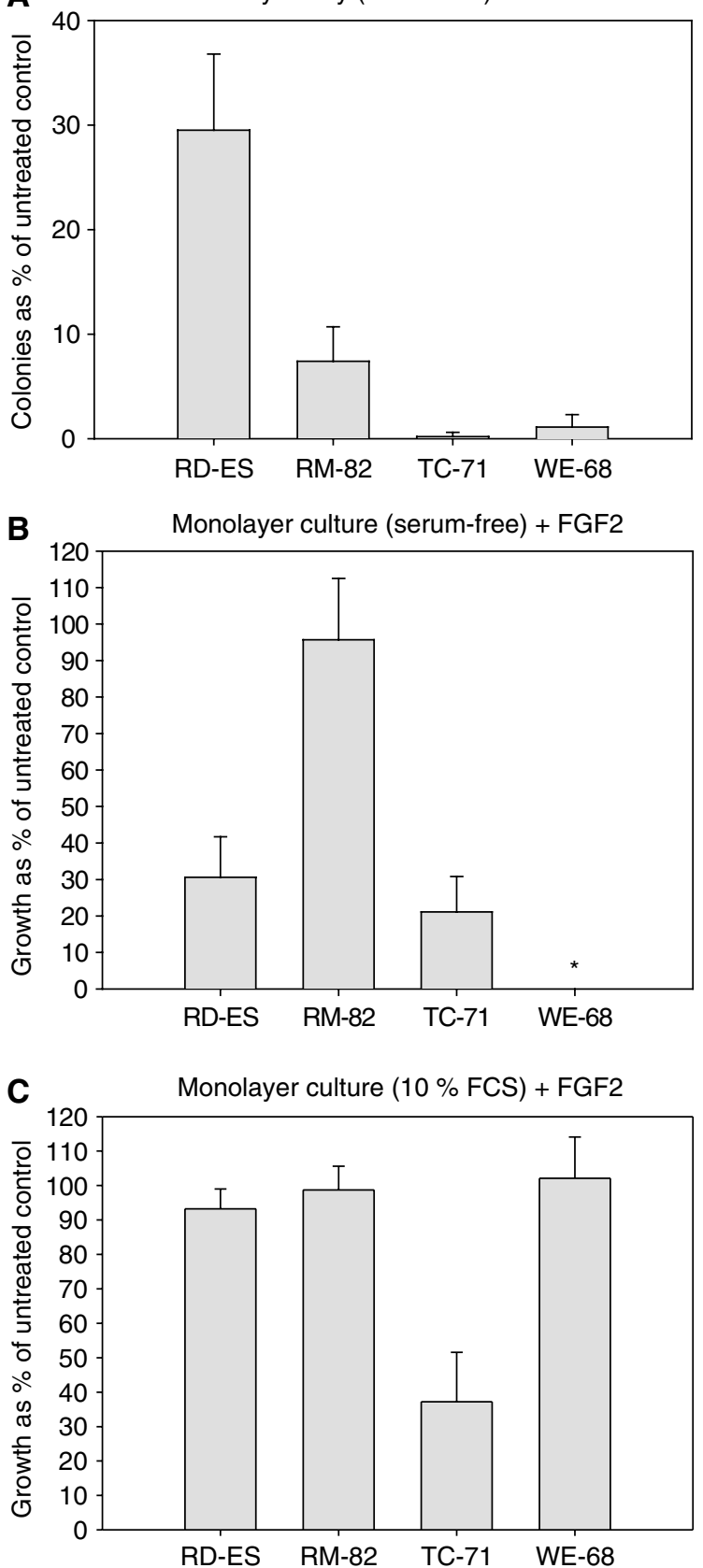

Figure 3 Comparison of the effects of $5 \mathrm{ng} \mathrm{ml}^{-1}$ FGF2 (A) in serumcontaining (I 5\% FCS) colony assays, (B) in serum-free adherent monolayer cultures and (C) in serum-containing adherent monolayer cultures, Integrin-mediated adhesion plus soluble serum factors had a strong synergistic effect in antagonising FGF2-induced apoptosis $(\mathbf{C})$. *WE-68 cells do not grow in serum-free adherent monolayer cultures.

Therefore, it was expected that this pathway may also be involved in serum- and adhesion-mediated resistance to FGF2induced apoptosis. LY294002 is a specific PI3K inhibitor (Vlahos et $a l, 1994)$ and its interaction with the ATP-binding pocket of PI3K has been well characterised (Walker et al, 2000). When $80 \mu \mathrm{M}$ LY294002 was added to serum-containing adherent monolayer cultures, tumour cell proliferation was dramatically reduced to approximately $40 \%$ in all four cell lines tested (Figure 4A). Under serum-free adherent monolayer culture condition, LY294002 had no effect on tumour cell proliferation in CADO-ES1 and TC-71
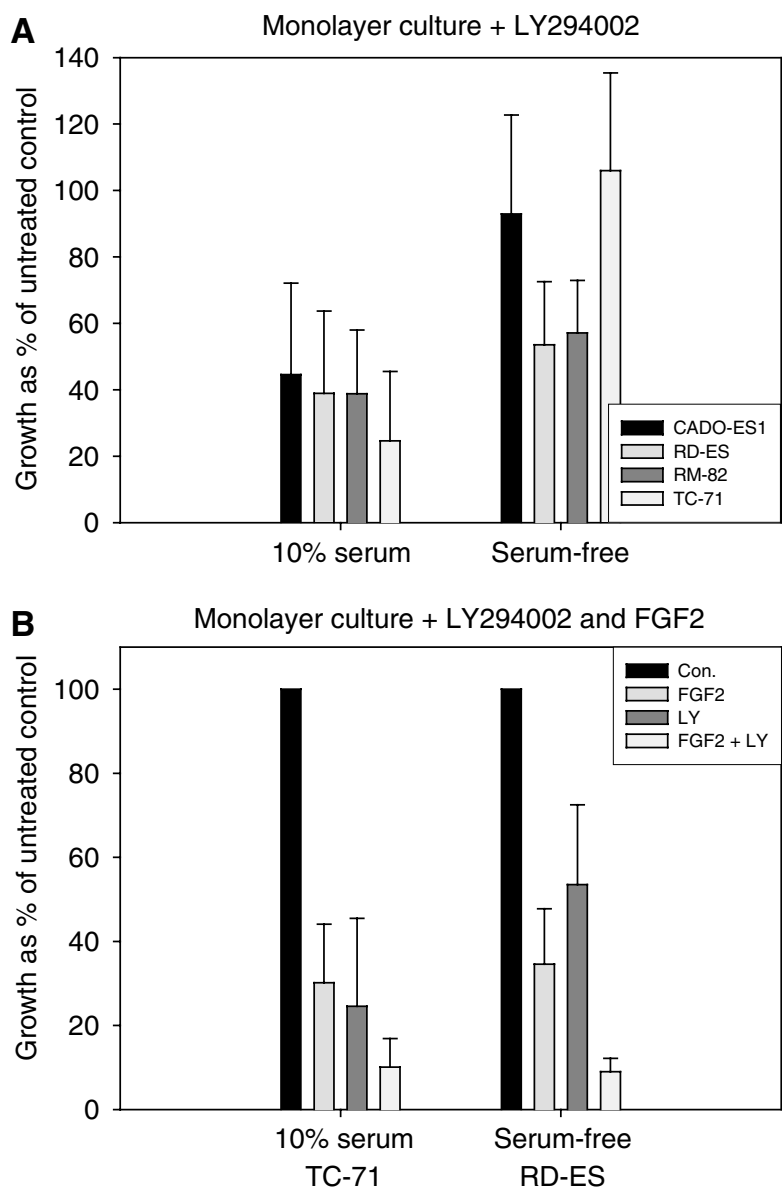

Figure 4 Inhibition of PI3K with LY294002 (80 $\mu \mathrm{M})$ decreased proliferation/growth of all Ewing tumour cell lines to approx. 38\% in serum-containing adherent cell cultures $(P<0.05)$ (A) (left columns). Under serum-free conditions, no significant inhibitory effect was seen with the cell lines CADO-ESI and TC-7I (P>0.7), while RD-ES and RM-82 showed a reduction in proliferation to approx. $45 \%$ (A) (right columns). The combination of LY294002 and FGF2 resulted in an increased sensitivity to FGF2 in serum-containing (TC 7I cells) (B) (left columns) and in serumfree adherent monolayer cultures (RD-ES cells) (B) (right columns) $(P<0.05)$. This indicates that PI3K-mediated survival signals are involved in antagonising FGF2-induced apoptosis.

cells, but a minor inhibitory effect on RD-ES and RM-82 cells (Figure 4A). This indicates that PI3K signalling is central in mediating serum-related survival signals in all cell lines as well as in mediating adhesion-related survival signals in RD-ES and RM82 cells.

In accordance with this assumption are the results obtained when TC-71 and RD-ES cells were cultured in the presence of FGF2 and LY294002 under serum-containing and serum-free conditions (Figure 4B). This combination resulted in an increased effect on FGF2-induced apoptosis under serum-containing culture conditions in TC-71 cells (Figure 4B left columns), indicating that inhibition of the serum-triggered PI3K survival signal renders TC71 cells more sensitive to FGF2-induced apoptosis. A similar effect was seen with RD-ES cells. When these cells were cultured under serum-free conditions, the inhibition of the adhesion-triggered PI3K survival signal resulted in sensitisation of these cells to FGF2induced apoptosis (Figure 4B, right columns).

These results show that PI3K signalling plays an important role in mediating serum- and/or integrin-related survival signals in Ewing tumour cell lines and that these survival pathways are involved in antagonising FGF2-induced apoptosis. 


\section{DISCUSSION}

We were able to confirm that FGF2 has a dose-dependent growthinhibitory effect on most Ewing tumour cell lines in vitro and that this growth inhibition is associated with induction of apoptosis. However, the biological and clinical impact of expression of FGF2 and its receptors by Ewing tumour cells remains obscure.

Activation of initiator caspases in FGF2-treated cells, including the receptor-triggered caspase 8 and lack of mitochondrial cytochrome $c$ release, had led to the hypothesis that FGF2-induced apoptosis may represent a new classical receptor-induced cell death pathway (Westwood et al, 2002). If this hypothesis is true, a caspase 8 inhibitor would be expected to protect Ewing tumour cells from FGF2-induced apoptosis. However, this assumption was not supported by our experiments. Inhibition of the receptorassociated initiator caspase 8 with z-IETD-FMK had no effect on Ewing tumour cell survival after exposure to FGF2. The delay in the occurrence of cell death after exposure to FGF2 indicates that induction of apoptosis may be a secondary event mediated by an unknown signalling cascade. Recently, it has been found out that FGF2-induced activation of JNK may play a crucial role in inducing apoptosis in Ewing sarcoma-related Askin tumour cells (Kim et al, 2004).

Nevertheless, four out of six Ewing tumour cell lines in vitro die after exposure to FGF2. In this context, it was surprising to observe that all Ewing tumour cell lines expressed FGF2 at the RNA and protein level (data not shown and Table 1). In contrast to L87/4 stroma cells, however, no FGF2 could be detected in the culture medium of the Ewing tumour cell lines (Table 1). Fibroblast growth factor lacks a secretory signal and is secreted by an ER/Golgi-independent mechanism (Engling et al, 2002). The lack of secretion of FGF2 under standard culture conditions may be one of the mechanisms by which Ewing tumour cells protect themselves from autocrine growth inhibition and induction of apopotosis.

However, lack of secretion of FGF2 by Ewing tumour cells is insufficient to explain formation, survival and metastasis of these tumour cells in or to the bone marrow microenvironment, which is a rich source of FGF2 (Brunner et al, 1993). Similar to the situation in patients, Ewing tumours metastasise at high frequency to bone and bone marrow in NOD/scid mice (Vormoor et al, 2001), indicating that the bone marrow microenvironment is supportive for growth and survival of these cells. It was, therefore, hypothesised that this FGF2-containing microenvironment itself is responsible for rendering Ewing tumour cells insensitive to FGF2. The complex interaction between tumour cells and their microenvironment and the importance of this interaction for tumour cell survival is increasingly been recognised (Liotta and Kohn, 2001). In this context, it has been pointed out that standard monolayer cultures may only poorly reflect the in vivo environment of Ewing tumour cells (Lawlor et al, 2002), emphasising the importance of culture conditions on in vitro results and their biological significance.

Using both adherent monolayer and non-adherent colony assays allowed dissection of important aspects of the interaction between Ewing tumour cells and their microenvironment. Both integrinmediated adhesion and soluble serum factors alone provide positive, though weak, survival signals partially antagonising FGF2 activity. However, adhesion combined with serum had a strong synergistic effect and caused Ewing tumour cell resistance to FGF2-induced cell death. These latter conditions most likely best reflect the microenvironment of human Ewing tumours in vivo, suggesting that FGF2-induced apoptosis may be a tissue culture artefact.

The serum as well as the adhesion signal is mediated to a large extent by the classical PI3K signalling cascade, as could be shown by inhibition experiments with LY294002. Phosphoinositide 3-OH kinase is a key regulator of growth factor- and integrin-related survival signals and the role of its downstream target, the kinase $\mathrm{AKT}$, has been well established in preventing apoptosis and supporting survival of many cell types (Datta et al, 1999; Danen and Yamada, 2001). However, it remains to be identified which soluble growth factors are responsible for this serum effect. The serum effect could not be attributed to IGF1, a growth factor thought to be one of the key mitogenic and survival factors in Ewing tumours. In addition, the resistance of Ewing tumour cells to imatinib mesylate, an inhibitor of c-KIT (Hotfilder et al, 2002), suggests that stem cell factor is also not a key survival factor in Ewing tumours.

Although it could be demonstrated that Ewing tumour cells escape FGF2-induced apoptosis through microenvironmentmediated survival signals, the biological function of FGF2 expression in Ewing tumour cells remains unknown. Under serum-free conditions, FGF2 has been shown to be a potent inducer of EWS/FLI1 protein expression and by this mechanism may stabilise the malignant phenotype (Girnita et al, 2000). Alternatively, FGF2 may be released under hypoxic stress as a potent angiogenic factor; it may affect bone remodelling and thus tumour progression by osteoclast recruitment (Collin-Osdoby et al, 2002), or it may act in a paracrine fashion by inducing growth factor production in bone marrow stroma cells (Zhang et al, 2002; Bisping et al, 2003).

In conclusion, although the biological function of FGF2 expression remains to be defined, several mechanisms could be identified by which Ewing tumour cells escape the detrimental effects of FGF2. These include the absence of FGF2 secretion under standard conditions and the modulation of inhibitory FGF2 signalling pathways by survival signals provided from integrindependent adhesion and soluble serum factors. The PI3K/AKT pathway is a key pathway involved in mediating the survival signals.

These survival signals need further investigation as they can be expected to play a central role in resistance to other apoptosisinducing agents including chemotherapeutic drugs (Aoudjit and Vuori, 2001) and will help to understand how Ewing tumour cells survive under sometimes hostile conditions in vivo. A better understanding of these survival signals will facilitate the development of treatments more specifically targeted against the tumour cells.

\section{ACKNOWLEDGEMENTS}

This work was supported by a grant to JV from the Deutsche Krebshilfe (10-1252-Vo 2). PS held a 'Nolte' scholarship from the Freundeskreis Knochenmarktransplantation Münster e.V. We gratefully acknowledge Andrea Lücke and Tanja Möllers for their excellent technical support and thank Dr C Rössig for helpful comments.

\section{REFERENCES}

Aoudjit F, Vuori K (2001) Integrin signaling inhibits paclitaxel-induced apoptosis in breast cancer cells. Oncogene 20: 4995-5004

Arvand A, Denny CT (2001) Biology of EWS/ETS fusions in Ewing's family tumors. Oncogene 20: 5747-5754
Bisping G, Leo R, Wenning D, Dankbar B, Padro T, Kropff M, Scheffold C, Kroger M, Mesters RM, Berdel WE, Kienast J (2003) Paracrine interactions of basic fibroblast growth factor and interleukin-6 in multiple myeloma. Blood 101: 2775-2783, doi:10.1182/blood-2002-09-2907 
Brunner G, Nguyen H, Gabrilove J, Rifkin DB, Wilson EL (1993) Basic fibroblast growth factor expression in human bone marrow and peripheral blood cells. Blood 81: 631-638

Collin-Osdoby P, Rothe L, Bekker S, Anderson F, Huang Y, Osdoby P (2002) Basic fibroblast growth factor stimulates osteoclast recruitment, development, and bone pit resorption in association with angiogenesis in vivo on the chick chorioallantoic membrane and activates isolated avian osteoclast resorption in vitro. J Bone Miner Res 17: 1859-1871

Danen EHJ, Yamada KM (2001) Fibronectin, integrins, and growth control. J Cell Physiol 189: 1-13

Datta SR, Brunet A, Greenberg ME (1999) Cellular survival: a play in three Akts. Genes Dev 13: 2905-2927

De Alava E, Gerald WL (2000) Molecular biology of the Ewing's sarcoma/ primitive neuroectodermal tumor family. J Clin Oncol 18: 204-213

Engling A, Backhaus R, Stegmayer C, Zehe C, Seelenmeyer C, Kehlenbach A, Schwappach B, Wegehingel S, Nickel W (2002) Biosynthetic FGF-2 is targeted to non-lipid raft microdomains following translocation to the extracellular surface of CHO cells. J Cell Sci 115: 3619-3631, doi:10.1242/ jcs.00036

Girnita L, Girnita A, Wang M, Meis-Kindblom JM, Kindblom L-G, Larsson O (2000) A link between basic fibroblast growth factor (bFGF) and EWS/ FLI1 in Ewing's sarcoma cells. Oncogene 19: 4298-4301

Hansen MB, Nielsen SE, Berg K (1989) Re-examination and further development of a precise and rapid dye method for measuring cell growth/cell kill. J Immunol Methods 119: 203-210

Hotfilder M, Lanvers C, Jurgens H, Boos J, Vormoor J (2002) c-KITexpressing Ewing tumour cells are insensitive to imatinib mesylate (STI571). Cancer Chemother Pharmacol 50: 167-169, doi:10.1007/ s00280-002-0477-8

Kim M-S, Kim CJ, Jung HS, Seo MR, Juhnn Y-S, Shin HY, Ahn HS, Thile CI, Chi JG (2004) Fibroblast growth factor 2 induces differentiation and apoptosis of Askin tumour cells. J Pathol 202: $103-112$

Knoop LL, Baker SJ (2001) EWS/FLI alters 5'-splice site selection. J Bio Chem 276: 22317 -22322, doi:10.1074/jbc.M008950200

Lawlor ER, Scheel C, Irving J, Sorensen PH (2002) Anchorage-independent multi-cellular shperoids as an in vitro model of growth signaling in Ewing tumors. Oncogene 21: 307 -318, doi:10.1038/sj.onc.1205053

Liotta LA, Kohn EC (2001) The microenvironment of the tumour-host interface. Nature 411: 375-379

Neufeld G, Mitchell R, Ponte P, Gospodarowicz D (1988) Expression of human basic fibroblast growth factor cDNA in baby hamster kidneyderived cells results in autonomous cell growth. J Cell Biol 106: 1385-1394

Ornitz DM, Itoh N (2001) Fibroblast growth factors. Genome Biol 2, reviews $3005.1-3005.12$

Santini MT, Rainaldi G (1999) Three-dimensional spheroid model in tumor biology. Pathobiology 67: 148 -157, doi:10.1159/000028065
Schweigerer L, Neufeld G, Gospodarowicz D (1987) Basic fibroblast growth factor as a growth inhibitor for cultured human tumor cells. J Clin Invest 80: $1516-1520$

Scotlandi K, Avnet S, Benini S, Manara MC, Serra M, Cerisano V, Perdichizzi S, Lollini PL, De Giovanni C, Landuzzi L, Picci P (2002) Expression of an IGF-1 receptor dominant negative mutant induces apoptosis, inhibits tunorigenesis and enhances chemosensitivity in Ewing's sarcoma cells. Int J Cancer 101: 11 -16, doi 10.1002/ijc.10537

Scotlandi K, Benini S, Sarti M, Serra M, Lollini PL, Maurici D, Picci P, Manara MC, Baldini N (1996) Insulin-like growth factor I receptormediated circuit in Ewing's sarcoma/peripheral neuroectodermal tumor: a possible therapeutic target. Cancer Res 56: 4570-4574

Sturla L-M, Westwood G, Selby PJ, Lewis IJ, Burchill SA (2000) Induction of cell death by basic fibroblast growth factor in Ewings's sarcoma. Cancer Res 60: 6160-6170

Toretsky JA, Thakar M, Eskenazi AE, Frantz CN (1999) Phosphoinositide 3hydroxide kinase blockade enhances apoptosis in the Ewing's sarcoma family of tumors. Cancer Res 59: 5745-5750

van Valen F (1999) Ewing's sarcoma family of tumors. In Human Cell Culture vol I, Masters JRW and Palsson B (eds) pp 55-85. London: Kluwer Academic Publisher

van Valen F, Winkelmann W, Jürgens H (1992) Type I and type II insulinlike growth factor receptors and their function in human Ewing's sarcoma cells. J Cancer Res Clin Oncol 118: 269-275

Vlahos CJ, Matter WF, Hui KY, Brown RF (1994) A specific inhibitor of phosphatidylinositol 3-kinase, 2-(4-morpholinyl)-8-phenyl-4H-1-benzopyran-4-one (LY294002). J Biol Chem 269: 5241 - 5248

Vormoor J, Baersch G, Decker S, Hotfilder M, Schafer KL, Pelken L, Rube C, van Valen F, Jürgens H, Dockhorn-Dworniczak B (2001) Establishment of an in vivo model for pediatric ewing tumors by transplantation into NOD/scid mice. Pediatr Res 49: $332-341$

Walker EH, Pacold ME, Perisic O, Stephens L, Hawkins PT, Wymann MP, Williams RL (2000) Structural determinants of phosphoinositide 3 kinase inhibition by wortmannin, LY294002, quercetin, myricetin, and staurosporine. Mol Cell 6: 909-919

Westwood G, Dibling BC, Cuthbert-Heavens D, Burchill SA (2002) Basic fibroblast growth factor (bFGF)-induced cell death is mediated through a caspase-dependent and p53-independent cell death receptor pathway. Oncogene 21: 809-824, doi 10.1038/sj.onc.1205128

Whang-Peng J, Triche TJ, Knutsen T, Miser J, Douglass EC, Israel MA (1984) Chromosome translocation in peripheral neuroepithelioma. N Engl J Med 311: $584-585$

Zhang X, Sobue T, Hurley MM (2002) FGF-2 increases colony formation, PTH receptor, and IGF-1 mRNA in mouse marrow stromal cells. Biochem Biophys Res Commun 290: 526-531, doi:1006/ bbrc. 2001.6217 